УДК 378.147:811.111(07)

DOI: https://doi.org/10.35387/od.2(20).2021.188-196

Дядченко Олена Вікторівна -

кандидат педагогічних наук, старший викладач кафредри англійської фрілології та методики викладання іноземних мов Мукачівського державного університету

ORCID iD: http://orcid.org/0000-0002-3415-4556

E-mail: legendakarpat77@gmail.com
Diadchenko Olena - Candidate of Pedagogical Sciences, senior teacher, Chair of the English Philology and methods of its teaching Mukachiv State University

\title{
ДИДАКТИЧНИЙ СУПРОВІД НАВЧАННЯ ДІЛОВОЇ АНГЛІЙСЬКОЇ МОВИ МАЙБУТНІХ УЧИТЕЛІВ ІНОЗЕМНИХ МОВ
}

Анотація. Стаття присвячена організації дидактичного супроводу профресійної підготовки майбутніх учителів іноземних мов в плані оволодіння ними англійською мовою для ділового спілкування. Дидактичний супровід навчання ділової англійської мови майбутніх учителів розелядається у двох площинах: дотримання дидактичних принципів навчання й забезпечення майбутніх учителів дидактичними матеріалами для формування й розвитку компетенції в діловому спілкуванні. Серед усіх дидактичних принципів для навчання ділової англійської мови необхідними $є$ принципи науковості, свідомості, доступності, зацікавленості, мотиваційної насиченості, повного засвоєння навчального матеріалу. В якості забезпечення дидактичними матеріалами для формування й розвитку компетенції в діловому спілкуванні розглядаємо електронний дидактичний матеріал, ефективність використання якого була підтверджена в процесі віддаленого навчання у період карантину. Використання електронного дидактичного супроводу уможливлює індивідуалізацію, диференціацію та інтенсифрікацію академічного процесу, посилення мотивації, фрормування професійної компетенції, здійснення контролю, візуалізацію навчальної інфоормації за допомогою мобільних додатків, моделювання міжкультурного спілкування, враховуючи соціокультурні відмінності носіїв анелійської мови й українців. Основні правила ділового спілкування, необхідні для взаєморозуміння, такі як дотримання різниці між фоормальним і нефрормальним спілкуванням та уникнення сленгу, жаргону, сумнівних виразів; використання офріційних мовних конструкцій, прийнятних в певній сфрері діяльності; уникання скорочень тощо згадуються в статmі.

Ключові слова: дидактичний супровід; майбутні вчителі іноземних мов; ділова англійська мова; електронний дидактичний матеріал. 
Diadchenko Olena

\title{
DIDACTIC ACCOMPANIMENT OF TEACHING BUSINESS ENGLISH TO FUTURE FOREIGN LANGUAGES TEACHERS
}

\begin{abstract}
Abstact. The article deals with the problem of organization of didactic accompaniment of teaching business English to future foreign languages teachers in Ukraine. The didactic accompaniment of teaching business English to teachers is regarded from the viewpoints of keeping didactic principles of foreign languages teaching and providing didactic materials for students to master their competences in business English. In the article didactic principles are referred as the answer to the question "How to organize the educational process?" Among all didactic principles worked out by Ya. A. Komensky some centuries ago and supplemented by modern scientists the following ones were researched: scientific approach, consciousness, accessibility, interest, motivation saturation, full comprehension of learned material. To form providing with didactic materials and development of competences in business English electronic didactic materials are under the author's consideration. These materials were widely used in the process of distance learning and their effectiveness was proved during COVID-19 quarantine. The main rules of business communication necessary for mutual understanding are dealt upon in the article. Usage of electronic didactic materials helps individualization, differentiation, intensification of the academic process, improving motivation, forming professional competence, providing control, visualization of necessary information by means of different mobile applications, modeling intercultural communication based on social grounds of native speakers and Ukrainians. The main rules of business communication necessary for mutual understanding are dealt upon in the article. They are: avoiding non-formal lexicon, abbreviations or shortenings, usage of slang or jargon, keeping to the norms of official communication in English speaking countries, etc.
\end{abstract}

Key words: didactic accompaniment; future foreign languages teachers; business English; electronic didactic materials.

Постановка проблеми, іï актуальність. Педагогічна освіта розширює свої горизонти під впливом постійних соціально-економічних та політичних змін у нашій країні й у світі, комп'ютеризацією освітнього процесу, запитами студентів нового покоління, які народились у 2000-х роках і не уявляють життя без сучасних електронних приладів та Інтернету. 3 огляду на це випускник педагогічного університету, майбутній учитель, має володіти новітніми технологіями навчання, навичками онлайн спілкування зі школярами, особистісними рисами, необхідними для встановлення контакту з учнями. Вчитель іноземної мови, володіючи англійською, німецькою чи іншою мовою, повинен стати для учнів провідником у новий світ іншомовних країн, познайомити школярів 3 життям і діяльністю людей за кордонами нашої держави.

Ще на початку 21-го століття вважалося, що вивчення англійської мови ділового спілкування (Business English) необхідне тільки для майбутніх економістів, перекладачів і політологів, однак стрімкий розвиток 
міжкультурних відносин, необмежений доступ до Інтернету, спілкування в соціальних мережах кардинально змінили ситуацію з використанням ділової іноземної мови. Сучасний учитель має бути готовим до розв'язання питань, вирішення яких потребує знання правил ділового спілкування i етикету. Тому зараз курс ділової іноземної мови $€$ обов'язковим для студентів усіх фрілологічних спеціальностей університетів.

Аналіз актуальних досліджень і публікацій. Проблеми вивчення ділової іноземної мови майбутніми фрахівцями нефілологічного профрілю досліджувались багатьма зарубіжними та вітчизняними вченими: T.St. Dudley-Evans, M.J. John (1998), M.Ellis, C. Johnson (1994), T. Hutchinson, A.Waters (1998). В Україні питання навчання англійської мови для ділового спілкування розглядались у курсі вивчення професійної іноземної мови. Специфріку навчання ділової іноземної мови студентів нефілологічних спеціальностей, а саме фахівців технічних спеціальностей, досліджували Р.О. Гришкова (2015), Н.О. Сура (2012). О.О. Зеліковська (2012), С.П.Кожушко, О.Б.Тарнопольський (2004), Г.О. Копил (2006) вивчали особливості формування компетентності в діловому спілкуванні майбутніх економістів; Я.В. Стрельчук (2012) присвятила дослідження менеджерам зовнішньоекономічної діяльності. Стосовно питань навчання ділової англійської мови майбутніх учителів іноземних мов зазначимо, що список фрахових публікацій у цій царині короткий, і обмежується роботами О.О. Заболотської (2010), О.В. Малихіна (2014), Р.Ю. Мартинової (2004), С.Ю. Ніколаєвої (2007) та інших науковців.

Метою статті $\epsilon$ висвітлення необхідності дидактичного супроводу в оволодінні українськими вчителями англійської мови діловою англійською мовою для успішного розвитку міжкультурного спілкування, роботою в Інтернеті, порозуміння зі школярами. У ході наукового пошуку передбачається: виявлення суперечностей в навчанні ділової англійської мови майбутніх економістів, бізнесменів, фахівців з міжнародних відносин та вчителів англійської мови; здійснення аналізу дидактичних принципів, дотримання яких дозволяє забезпечити ефективність навчання ділової англійської мови майбутніх учителів; дескрипція переваг електронного дидактичного супроводу навчання ділової англійської мови майбутніх учителів англійської мови.

Викладення основного матеріалу дослідження. Як відомо, від досконалого володіння іноземною мовою для ділового спілкування залежить ефективне співробітництво вітчизняних учителів англійської мови 3 колегами в інших країнах, взаєморозуміння та співпраця 3 представниками бізнесу для кращого задоволення потреб учнів щодо володіння іноземною мовою для обрання майбутньої професії. Оскільки питання формування компетенції в англомовному діловому спілкуванні майбутніх учителів іноземної мови не може вважатись достатньо вивченим, сконцентруємо увагу на дидактичному супроводі навчання ділової англійської мови майбутніх учителів.

У дослідженні ми розглядатимемо дидактичний супровід навчання ділової англійської мови майбутніх учителів у двох площинах: дотримання 
дидактичних принципів навчання й забезпечення майбутніх учителів дидактичними матеріалами для формування й розвитку компетенції в діловому спілкуванні.

Як стверджує Р.Ю. Мартинова, «під принципами навчання розуміють вихідні положення, які визначають різні сторони навчання зміст, методи, засоби, форми. Дидактичні принципи відображають загальні вимоги до формування змісту освіти й організації навчально-виховного процесу - як у цілому, так і в окремих його ланках. Структура дидактичних принципів зумовлюється структурою законів і закономірностей навчання» (Мартинова, 2004, с. 47). На думку С.Ю. Ніколаєвої, принципи навчання це відповідь на запитанняя «Як організувати навчальний процес?» (Ніколаєва, 2007, с.51]. Ми схиляємося до думки, що дидактичні принципи, запропоновані ще Я.А. Коменським і доповнені сучасними вченимидидактами (О.Я. Савченко, О.В. Малихін, О.М. Топузов та ін.), є основою освітнього процесу, і забезпечують сприймання навчального матеріалу, його осмислення, запам'ятовування й використання. Тож до принципів, які мають забезпечити дидактичний супровід навчання ділової ангійської мови, нами віднесено: принципи науковості, свідомості, доступності, зацікавленості, забезпечення мотиваційної насиченості, принцип повного засвоєння навчального матеріалу. Ці дидактичні принципи в поєднанні 3 методичними принципами навчання іноземної мови (домінуючої ролі вправ, використання рідної мови, апроксимації, взаємопов'язаного навчання чотирьох видів мовленнєвої діяльності: читання, говоріння, аудіювання, письма) сприяють підвищенню ефективності освітнього процесу й формуванню відповідної компетентності майбутнього вчителя у сфрері оволодіння діловою англійською мовою (Business English).

Дотримання дидактичних принципів потребує виявлення суперечностей між вимогами сфер працевлаштування до оволодіння майбутніми вчителями англійської мови сучасною діловою лексикою та рівнем іншомовної підготовки студентів у ЗВО. Ділова англійська мова найбільш поширена у сфері економіки, торгівлі, міжнародних відносин. Це ті галузі знань, у яких найменш обізнані студенти-фрілологи, майбутні вчителі іноземної мови, тому найсуттєвішою перепоною для оволодіння діловою мовою для них $є$ відсутність елементарних знань з економіки, міжнародних відносин, торгівлі тощо. Тому на заняттях з ділової англійської мови викладач має поступово вводити студентів у сферу економічних понять, міжнародних відносин, ділових стосунків тощо. В цьому йому можуть допомогти викладачі інших кафедр на основі міждисциплінарної координації. До того ж, такі поняття з курсу ділової англійської мови, як робота в команді (team work), управління часом (time management), прийняття рішень (decision taking) наразі використовуються в процесі викладання професійних дисциплін: методики навчання іноземної мови, психології, педагогіки вищої школи та ін.

За В.М. Андреєвим, дидактика та методика перебувають у тісному взаємозв'язку: дидактика спирається на методику викладання конкретних навчальних дисциплін, беручи конкретні факти, приклади та матеріали, що 
дають обґрунтування для узагальнень. Разом з тим пізнання дидактичних закономірностей беруться на озброєння предметними методиками і використовуються для подальшого вдосконалення викладання навчальних дисциплін (Андреева, 1989, с. 24-28). Р.Ю. Мартинова переконливо доводить, що «метод навчання слід розглядати не лише з психологічних і лінгвістичних позицій, а також 3 дидактичних, згідно 3 якими він визначається як упорядкований спосіб взаємопов'язаної діяльності викладача і студента що приводить до оволодіння знаннями, навичками й уміннями, формування світогляду, розвитку здібностей» (Мартинова, 2004, с.45). На думку О.Б. Тарнопольського й С.П. Кожушко, методика викладання англійської мови для ділового спілкування студентів економічних та фрілологічних спеціальностей відрізняється змістом навчання (Тарнопольський, \& Кожушко, 2004) оскільки майбутні вчителі вже мають відповідні культурологічні й лінгвосоціокультурні знання, засвоєні в процесі опанування курсу країнознавства, та усвідомлюють розбіжності у стандартній (нормативній) поведінці носіїв іноземної мови й українців у ситуаціях ділового спілкування.

У курсі навчання ділової іноземної мови відбувається розвиток таких умінь як співставлення, аналогія, узагальнення, перенесення, порівняння, класифікація, аналіз, синтез; вони є необхідними в активізації навчальної діяльності студентів і в майбутній професійній діяльності. Працюючи над темами «Діловий етикет і протокол», «Письмове спілкування з носіями мови», «Врахування соціокультурних розбіжностей у процесі співпраці з іноземцями», студентам слід засвоїти основні правила ділового спілкування:

- різницю між формальним і неформальним спілкуванням та уникати сленгу, жаргону, сумнівних виразів;

- використовувати офріційні мовні конструкції, прийнятні в певній сфері діяльності;

- уникати скорочень (examination not exam, cellphone not cell, television not simply telly or TV;

- офіційне мовлення, як і спільні бізнесові інтереси, поєднує ділових людей, сприяє взаєморозумінню, налаштовує на подальшу співпрацю.

Тож цілеспрямована підготовка майбутнього вчителя англійської мови до ділового спілкування забезпечує студенту оволодіння сукупністю необхідних компетенцій, розвиток специфічних здібностей для адекватного вирішення завдань професійної діяльності; універсальність знань і діяльності для розвитку пізнавальних здібностей людини; сприяння розвитку творчого мислення, пам'яті, тобто досягнення одного з найвищих рівнів процесу інтелектуалізації.

Останнім часом, 3 огляду на запровадження дистанційного навчання в період карантину, поряд із традиційними засобами супроводу освітнього процесу (навчально-методичний комплекс, додаткова література, словники) набули популярності електронні дидактичні 
матеріали - цілеспрямовано розроблені документи для використання в академічному процесі за допомогою прикладних програм загального призначення і побудовані відповідно до змісту навчальної теми і методики викладання дисципліни. Використання електронних дидактичних матеріалів дозволяє викладачу, який спілкується зі студентами в Skype чи Zoom на платформі MOODLE:

- індивідуалізувати, диференціювати та інтенсифікувати академічний процес, спираючись на принципи свідомості й доступності;

- посилити мотивацію навчання через використання різних джерел інформації, забезпечивши дотримання принципу мотиваційної насиченості;

- формувати професійні компетенції в умінні орієнтуватися в проблемі і шукати шляхи її вирішення через комп'ютерне дослідження та моделювання;

- змінити характер пізнавальної діяльності студентів шляхом підтримки особистих намагань сформувати власний стиль навчальної роботи;

- діагностувати помилки й оцінювати результати навчальної діяльності кожного студента;

- здійснювати контроль із зворотним зв'язком за наслідками роботи студента, забезпечуючи дотримання принципу повного засвоєння навчального матеріалу;

- візуалізувати навчальну інформацію за допомогою мобільних додатків;

- моделювати міжкультурне спілкування, враховуючи соціокультурні відмінності носіїв англійської мови й українців;

- забезпечити доступ до джерел інформації (Інтернету, електронних довідників і т. д.);

- розвивати інформаційну компетентність майбутнього вчителя іноземної мови, навчити працювати з автентичними діловими паперами й документами.

Зміст навчання ділової іноземної мови залежить від того, який склад компонентів цього змісту береться до уваги як вихідний, початковий. У методиці це питання донині не знайшло кінцевого рішення. Одні автори обмежують ці компоненти навичками та уміннями читання, усного мовлення та письма. Інші вважають необхідним ввести до їх складу мовний матеріал. Треті значно розширюють список, включаючи до нього ще й тексти як зразки мовлення, різну лінгвістичну інформацію, мовні поняття, не притаманні рідній мові. Але в будь-якому випадку зміст навчання повинен базуватися на засвоєнні студентами основних правил ділового спілкування; здобувачі вищої освіти мають чітко диференціювати сфери вжитку формальної і неформальної лексики. Особливо це стосується молоді, яка в своєму колі часто послуговується сленгом, жаргоном, ідіоматичними виразами, використовує скорочення й абревіатури. Порівнюючи писемне спілкування в Інтернеті, в чатах і соціальних мережах 
з нормами формального обміну думками ділових людей, можна дійти висновку, що люди комунікують різними мовами.

Дотримання певної послідовності при відборі змісту навчання ділової іноземної мови $є$ необхідним. Ця послідовність повинна йти від компонентів, які складають комунікативний аспект, через компоненти, які входять до лінгвістичного аспекту, і завершатися компонентами психофізіологічного та суспільного аспектів. Саме такий підхід відповідає загальнометодичному принципу комунікативності, оскільки відбір цілком і повністю відштовується від комунікації та проводиться, виходячи з їі потреб.

Висновки і перспективи подальших досліджень. Дидактичний супровід навчання ділової англійської мови майбутніх учителів іноземної мови спирається на відповідні дидактичні (науковості, свідомості, доступності, зацікавленості, забезпечення мотиваційної насиченості, повного засвоєння навчального матеріалу) й методичні (домінуючої ролі вправ, використання рідної мови, апроксимації, взаємопов'язаного навчання чотирьох видів мовленнєвої діяльності: читання, говоріння, аудіювання, письма) принципи та здійснюється з урахуванням змін в освітньому процесі, що викликані пандемією COVID-19, а саме переходом до запровадження електронного дидактичного супроводу в режимі віддаленого чи дистанційного навчання.

Виявлені в ході дослідження суперечності в навчанні ділової англійської мови майбутніх вчителів англійської мови, а також економістів, бізнесменів, фахівців з міжнародних відносин засвідчили, що майбутні викладачі іноземних мов мають значні переваги в оволодінні мовою ділового спілкування, оскільки такі поняття з курсу ділової англійської мови, як робота в команді (team work), управління часом (time management), прийняття рішень (decision taking) наразі використовуються в процесі викладання професійних дисциплін на фрілологічних фракультетах університетів: методики навчання іноземної мови, психології, педагогіки вищої школи та ін. і не $є$ новими для майбутніх учителів. Методика викладання англійської мови для ділового спілкування студентів економічних та фрілологічних спеціальностей відрізняється відповідно до змісту навчання, оскільки майбутні вчителі вже мають відповідні культурологічні й лінгвосоціокультурні знання, засвоєні в процесі опанування курсу країнознавства, та усвідомлюють розбіжності у стандартній (нормативній) поведінці носіїв іноземної мови й українців у ситуаціях ділового спілкування. Основні правила ділового спілкування (різницю між фрормальним і неформальним спілкуванням та уникати сленгу, жаргону, сумнівних виразів; використовувати офіційні мовні конструкції, прийнятні в певній сфері діяльності; уникати скорочень; офіційне мовлення) мають бути засвоєні всіма учасниками ділового спілкування.

Описані в статті переваги електронного дидактичного супроводу навчання ділової англійської мови майбутніх учителів англійської мови дозволяють сподіватись, що наукова спільнота зверне увагу на 
необхідність розробки процедури широкого запровадження електронного дидактичного супроводу навчання не тільки ділової англійської мови, але й інших академічних дисциплін.

Проблеми дидактичного супроводу навчання ділової англійської мови майбутніх учителів англійської мови потребують подальших досліджень у контексті усвідомлення різниці між звичайним і діловим англомовним спілкуванням, інтенсифрікації процесу розробки електронних дидактичних матеріалів та способів контролю за їх виконанням, залучення студентів-фрілологів до підвищення рівня власної комп'ютерної грамотності.

\section{Список використаних джерел}

Андреева, В. М. (1989). Методика активизации самостоятельной работы студентов ускоренного обучения. Организация самостоятельной работы студентов в процессе изучения общественных наук. Л. : Изд-во ЛГУ, 6, 24-28.

Гришкова, Р. О. (2015). Методика навчання англійської мови за професійним спрямуванням студентів нефілологічних спеціальностей: навчальний посібник для студентів вищих навчальних закладів. Миколаїв : Вид-во ЧДУ ім. Петра Могили. 220 с.

Заболоцька, О.О. (2010). Методика викладання іноземних мов у ВНЗ. Херсон: Айлант. 406.

Малихін, О.В., Павленко, І. Г., Лаврентьєва, О. О., \& Матукова Г.І. (2014). Методика викладання у вищій школі. К.: КНТ. 262.

Мартинова, Р.Ю. (2004). Цілісна загальнодидактична модель змісту навчання іноземних мов. К.: Вища школа. 454.

Ніколаєва, С.Ю. (2007). Методика навчання іноземних мов у середніх навчальних закладах. К.: Ленвіт. 263.

Стрельчук, Я. В. (2012). Формування культури морально-ділових відносин у менеджерів зовнішньоекономічної діяльності: монографія. Херсон: Грінь Д.С., 258.

Тарнопольський, О.Б., \& Кожушко, С.П. (2004). Методика обучения английскому языку для делового общения. К.: Ленвит. 192.

Тарнопольський, О.Б. (2006). Методика навчання іншомовної мовленнєвої діяльності у вищому мовному закладі освіти. К.: Фірма «ІНКОС». 248.

\section{References (translated and transliterated)}

Andreeva, V. M. (1989). Metodika aktivizacii samostoyatel'noj raboty studentov uskorennogo obucheniya [Methodology for enhancing the independent work of accelerated students]. Organizaciya samostoyatel'noj raboty studentov $v$ processe izucheniya obshchestvennyh nauk. L.: Izd-vo LGU, 6, 24-28 [in Russian].

Gryshkova, R. O. (2015). Metodyka navchannia anhliiskoi movy za profesiinym spriamuvanniam studentiv nefilolohichnykh spetsial-nostei [Methods of teaching English in the professional direction of students of non-philological specialties]: navchalnyi posibnyk dlia studentiv vyshchykh navchalnykh zakladiv]. Mykolaiv : Vyd-vo ChDU im. Petra Mohyly. 220 [in Ukrainian].

Zabolotska, O.O. (2010). Metodyka vykladannia inozemnykh mov u VNZ [Methods of teaching foreign languages in higher education]. Kherson: Ailant. 406 
[in Ukrainian].

Malykhin, O.V., Pavlenko, I. H., Lavrentieva, O. O., \& Matukova, H. I. (2014). Metodyka vykladannia u vyshchii shkoli [Methods of teaching in higher education]. Kyiv: KNT. 262 [in Ukrainian].

Martynova, R.lu. (2004). Tsilisna zahalnodydaktychna model zmistu navchannia inozemnykh mov [A holistic general didactic model of the content of foreign language teaching]. Kyiv: Vyshcha shkola. 454 [in Ukrainian].

Nikolaieva, S.lu. (2007). Metodyka navchannia inozemnykh mov u serednikh navchalnykh zakladakh [Methods of teaching foreign languages in secondary schools]. Kyiv: Lenvit. 263 [in Ukrainian].

Strelchuk, Ya. V. (2012). Formuvannia kultury moralno-dilovykh vidnosyn u menedzheriv zovnishnoekonomichnoi diialnosti: monohrafiia [Formation of a culture of moral and business relations in managers of foreign economic activity]. Kherson: Hrin D.S., 258 [in Ukrainian].

Tarnopol's'kij, O.B., \& Kozhushko, S.P. (2004). Metodika obucheniya anglijskomu yazyku dlya delovogo obshcheniya [Methods of teaching English for business communication]. Kyiv: Lenvit. 192 [in Russian].

Tarnopolskyi, O.B. (2006). Metodyka navchannia inshomovnoi movlennievoi diialnosti u vyshchomu movnomu zakladi osvity [Methods of teaching foreign language speech activity in a higher language educational institution]. Kyiv: Firma «INKOS». 248 [in Ukrainian]. 